This is an open access article under the CC BY-NC-ND license (https://creativecommons.org/licenses/by-nc-nd/3.0/) Issue II, November 2019

ISBN 978-601-323-144-0

https://doi.org/10.31643/2019.030

\author{
Gulzhaina Kassymova \\ Abai Kazakh National Pedagogical University, \\ Kazakhstan; Graduate School Universitas Negeri \\ Yogyakarta (Yogyakarta State University), \\ Indonesia \\ E-mail: zhaina.kassym@gmail.com \\ ORCID ID 0000-0001-7004-3864
}

Sazhida Dossayeva

National academy of sciences of the Republic of Kazakhstan

E-mail: s.dosaeva@mail.ru ORCID ID 0000-0002-6011-5198

\author{
Bruri Triyono \\ Graduate School Universitas Negeri \\ Yogyakarta (Yogyakarta State University), \\ Indonesia \\ E-mail: bruritriyono@uny.ac.id \\ ORCID ID 0000-0001-5720-9604
}

\title{
Cognitive competence and electronic learning
}

\begin{abstract}
This article investigates cognitive psychology and electronic learning and shows experimental review about cognitive development which were carried out by modern scientists. Authors studied the historical background of the term 'cognition' and outlined that e-learning is a key factor to develop students' cognitive competence. They also gave more information about distance education and universities that provide online education worldwide. It was concluded that cognitive development is more effective at a younger age than in adult education because the cognitive development process occurs very slowly in adult education. Additionally, online education should serve the society in a beneficial way since there are myriad online providers in open access.
\end{abstract}

Keywords: cognitive, competence, development, e-learning, distance education, university, students.

\section{Introduction}

The cognitive revolution dominated psychology in the United States from the 1920s to 1960s. There have been numerous mysteries inside the organism which were hard to ignore for scientists. Psychology researchers began to investigate our brain that regulates our thoughts, feelings, and behavior. Child development researchers found out that newborn babies pass several stages of cognitive development in the way they think about their environment whereas animal researchers were noticing that inborn biological instincts often interfere with learning. There was and still could be a dramatic cognitive revolution change in psychology. The term 'cognition' implies mental processes such as a stimulus and response including memories, expectations and images. It means that the term 'cognition' typically refers to thinking, knowing, and remembering processes $[1, \mathrm{p} .9]$.

According to Collins dictionary, a word 'cognitive' means relating to the mental process which is involved in knowing, learning, and understanding things [2]. Another online vocabulary dictionary source defines 'cognitive' from a etymological view. It says the adjective 'cognitive' comes from the Latin language [3] 'cognoscere' which means getting to know and it refers to the ability of the brain. How our brain thinks 
and shows reason, as opposed to feeling, depends on our thinking ability. The English language has borrowed this word 'cognition' from the Italian language 'cognoscente' (noun) [kän-yə-'shen-tē] since the late 1700s [4]. There are many English words with 'cogn-" such as 'cognizant' which means aware and 'recognize' which means currently knowing someone because you have been knowing this person for a long time. 'Cognizance' and 'cognition' came from 'cognoscere' [3, 4].

The cognitive psychology of Wundt and James were swept for years with the rise of behaviorism in the United States of America. The subject was considered non-scientific. However, the invention of the computer was a big motivation for different researchers including educators, scientific developers and psychologists and woke up interest in the mental process. Modern researchers believe that the leading changes in education associated with computers, are that electronic learning develops students' cognitive skills [5]. Nowadays, there are many educational developers who are devoted to developing high-level cognitive skills in higher education by using e-learning. They are investigating a number of e-learning benefits which contribute to developing students' high-level cognition and also identifying some restrictive factors which make e-learning difficult for students during autonomous studies [6]. Computers provided a new model of the human mind. The computers receive symbols and convert them into a special code, store the information, then retrieve it from memory once it is necessary.

Another motivation came from the work of Swiss psychologist Jean Piaget. In the XX century, Jean Piaget studied child development how a child thinks and perceives the world. He made various tasks for child development and came to the conclusion that all children from infancy and adolescence pass different cognitive stages. Developers within the study of language additionally contributed to the cognitive revolution, for instance, B. F. Skinner (1957) studied the acquisition of language, whereas Chomsky's theory stimulated a great deal of interest in psycholinguistics. This topic played a key role in the cognitive revolution in history $[1$, p. 10]. The invention of artificial intelligence is making its way to the higher education system in a variety of ways. It might be academically used to help educational institutions increase the numbers of online learners because of its myriad benefits for both teachers and students in terms of personal cognitive development.

\section{Cognitive development}

Cognitive development is very important in the labour market. According to the American report in 1991, a survey was conducted among workers and employers in fifty occupations. In a result, necessary skills were categorised into basic skills, thinking skills, personal qualities and a set of the workplace competencies. Except for reading, writing, and math skills, listening and speaking skills are included in basic skills. Thinking skills include creative thinking, making a decision, solving a problem, the capability to learn. Personal qualities cover personal responsibility, communication skills, self-esteem, self-control, honesty etc. Survey conductors divided workplace competencies into five groups: First competence is to be able to allocate resources correctly, for example, time and finance management. The second one includes interpersonal skills such as teamwork, mentoring and teaching skills. The next ones are to acquire and to use the information and the ability to understand the working system. The last workplace competence is the ability to use the latest technology well [8, p.29]. By analyzing this survey result we can conclude that it is very important to develop cognitive competence while students are studying. After graduation from university, they should be competent to work in our labour market.

Recent research [8] has studied measuring cognitive (ability to learn, to process, to apply knowledge, to make a decision effectively, to analyze situations and to evaluate them etc.) and non-cognitive (selfcontrol, trust, attentiveness, self-esteem, self-efficacy, openness to experience, empathy etc.) skills of human beings. Researchers made a review of various educational programs about cognitive and non-cognitive skills at the different life cycle. Cognitive competence has multiple aspects. Two types of intelligence are distinguished by psychologists: fluid intelligence and crystallised intelligence. The first one refers to the rate at which students learn and the other one acquired knowledge. They came to the conclusion that these both skills are changeable over the life span and it depends on the various remediation programs on how to develop cognitive and non-cognitive skills. Many childhood and adult educational programs have been introduced in less developed countries. One of them is called 'Jamaican Supplementation Study'. It is a twoyear nutritional and stimulation program at the age of 9-24 months. Participants got milk-supplementation and played with their stimulated mother in an effective manner. According to this study, researchers claim that both interventions enabled early cognitive development. Food supplementation improved short-term cognitive skills whereas the stimulation had long-term effects on cognitive and non-cognitive skills at the age of 17-18. This stimulation method also improved earnings to $33 \%$ in later life. Such kind of other programs have been used to multiple age groups and targeted at cognitive and non-cognitive development of infancy, kindergarten, elementary school pupils, adult students. 
Another example of the cognitive and non-cognitive development program is called 'Seattle Social Development Project' (SSDP). SSDP was devoted to public elementary school in the high-crime district in the city Seattle, Washington. This program was aimed at the grades from 1 to 6 . It was an interrelated method among pupils, parents and teachers. Parents and teachers attended different training courses based on cognitive and non-cognitive development curriculum. As a result, this program enabled an increase in the pupils' self-efficacy at the age of 21 to 24 and they benefited from earning good income at the age between 24 and 27 [8, p.38-60]. In comparison with adults, early childhood and elementary school programs are much more effective than a later-life learning process (Tim Kautz, James J. Heckman, Ron Diris, Bas ter Weel, Lex Borghans, 2017). That is why adult education should be properly effective for higher institutions' students. Nowadays, higher institutions' educators have to consider which teaching method is the most effective for students' cognitive development and implement individual teaching approaches. One of the latest teaching approaches might be electronic learning (e-learning) which requires students to learn autonomously and enables them to develop their cognitive competence. In the next section, we will discuss the development of students' cognitive competence based on e-learning.

\section{Cognitive competence}

Cognitive competence is a set of mental process. According to Van Lehn (1995, in Reference 6), the acquisition of cognitive skills is to develop the ability to solve problems in intellectual tasks, where success is determined more by knowledge of the individual. Cognitive skills are abilities that make individuals responsible for their actions, allowing them to interact with the environment. The basic structure which is formed by these skills might be called cognitive competence, allowing individuals to identify and classify information, raise and build issues, rules and to solve problems [6]. XXI century labour market needs extremely educated professionals with high-level cognitive abilities for lifelong learning purpose. There is little doubt that technology and science are always advancing and workers ought to catch up them on an everyday basis. Educators ought to contribute to students whereas they are making ready young students to the labour market to be competent after graduating from university. The foremost vital stage of this academic system is to set a goal to develop students' cognitive skills like critical thinking, solving problems, analyzing a situation and making decision etc. Since taught subjects require students to solve problems, to think critically and to analyze the results after a conducted experiment in the laboratory [7]. That is why educators should develop students' cognitive competence at all levels of the education system as well as in e-learning.

The invention of information technology has already created e-learning as another teaching approach to face to face teaching and therefore the advantages of e-learning outweigh its downside. E-learning equally opens a door into knowledge. It is possible to learn at any time and any place. It additionally allows learning properly just in case if a student does not perceive a subject topic, there is always a chance to repeat and analyze the information. In traditional lessons students used to get information from a teacher and time is limited, for instance, a lecturer comes to teach them for an hour and conveys information quickly. However, students who do e-learning do not have a time limit to be in the classroom at a fixed time. They do lessons whenever they want at their pace. It means students have an opportunity to acquire knowledge equally regardless of their study ability.

There was an interview survey conducted by Walter Ruben in 2012 [6] to elicit views and opinions of participants in e-learning. The survey reported in 2008. A total of twenty-six individuals from six universities were interviewed representing twenty-six online courses. According to Walter Ruben's survey about teaching and learning practices associated with the development of high-level skills in higher education, one interviewee claims that students will not start to think critically by giving them an hour classroom discourse. Students should be involved in conversations, in discussions, or joint question analysis and texts. Interview participants reassured that it is necessary to make students deal with elements that motivate discussion and critical thinking. Reading and discussion of books should be obligatory for critical thinking development. Students effectively benefit from doing lessons by themselves, not from being told by an educator, therefore there exists active learning in online education. E-learning allows students to communicate in both synchronous and asynchronous form completing online tasks based on various materials such as texts, audio, video etc. Students should be proactive in the e-learning process. E-learning system requires students' participation and interaction with a teacher and peers as well as with online materials [6].

E-learning includes a kind of autonomous study skill. Autonomous study is a targeted mental process because it is accompanied and supported by an individual's activity in doing online assignments. A student makes a decision on achieving an educational goal. According to those interview survey participants carried out by Walter Ruben (2012), students should be well instructed on how to do online lessons, otherwise, they will get unmotivated. They also clarified that there are e-learning restrictive factors such as technical 
problems, unwell internet connection, challenges to keep students motivated and autonomous study lack in students. As a result, teachers might lose students forever. Therefore, teaching is no easy task for developing students' cognitive competence. It is always necessary to create an emotional atmosphere for students in the e-learning process without stress consequences.

\section{Electronic learning (e-learning)}

E-learning is an implementation of electronic media for a variety of learning purposes to facilitate the delivery of distance education, online learning or blended learning. There are many terminologies regarding the e-learning which includes distance education, blended learning, hybrid learning, online learning etc. J. J. Roberts [9] asserts that distance education implies a teaching and learning processes which take place separately from each other. It means that there is a geographical and physical separation between a teacher and a student in both place and time. Learners acquire knowledge separated from their teachers whereas students interact with educational materials, classmates and teachers in a blended learning system through both an online learning environment. The University of Central Florida, with more than 60,000 students, has been a leader in the development of blended learning system. This teaching approach incorporates the flexibility and convenience of online learning with traditional teaching methods [10].

Nowadays, there are many top mega universities which use distance education system. According to J. J. Roberts (Table 1), the United Nations Human Development Report indicated top 10 mega universities in developing countries in 2016. Such universities have got more than 100, 000 students who study in distance education at a degree level. Table 1 gives more information about the top mega universities worldwide. It can be concluded that a distance education university has been successful up to date. For example, Unisa University in South Africa has been existing as the first distance education teaching university since 1946 [9].

Table 1 Top 10 mega universities in developing countries

\begin{tabular}{|l|l|c|}
\hline University & Country & Number of students \\
\hline IGNOU & India & $4,000,000$ \\
\hline Open University of China & China & $2,700,000$ \\
\hline Anadolu & Turkey & $1,974,000$ \\
\hline Allama Iqbal & Pakistan & $1,326,000$ \\
\hline Bangladesh OU & Bangladesh & 650,000 \\
\hline Terbuka & Indonesia & 646,000 \\
\hline Shanghai Open University & China & 610,000 \\
\hline Dr BR Ambdekar & India & 450,000 \\
\hline Unisa & South Africa & 350,000 \\
\hline NOUN & Nigeria & 300,000 \\
\hline
\end{tabular}

However, there is no exact definition of mega-university. It is largely believed that "megauniversities are not defined just by quantity." A big amount of online learners is a key characteristic of distance education. The condition of online education in the United States of America (the USA) has been successful as well. Students, who consider online learning now, have a wide range of options to choose from the "mega-universities." For instance, there are such universities like Southern New Hampshire, Liberty, Grand Canyon, and Western Governors, and all these universities boast massive online enrollments. Initially, online education was implemented mainly for-profit universities, for example, the University of Phoenix, but the environment is changing. Currently, it will be found that nonprofit universities and large traditional 
schools are investing heavily in the development of online programs with goals of their own "mega" enrollments. Table 2 shows just a few examples of schools implementing strategies for continued growth [10].

Table 2 The USA's mega universities

\begin{tabular}{|l|c|c|}
\hline \multicolumn{1}{|c|}{ University } & $\begin{array}{c}\text { Students more } \\
\text { than }\end{array}$ & $\begin{array}{c}\text { Online programs } \\
\text { more than }\end{array}$ \\
\hline Arizona State University & 25,000 by 2025 & 200 \\
\hline $\begin{array}{l}\text { Southern New Hampshire } \\
\text { University }\end{array}$ & 300,000 by 2023 & 150 \\
\hline The State University of New York & 400,000 & 500 \\
\hline Purdue University Global & 30,000 & 175 \\
\hline Western Governors University & $110,534 *$ & $55^{*}$ \\
*Source retrieved from google engine & &
\end{tabular}

\section{Conclusion}

In conclusion, there are many studies and techniques for developing cognitive skills in adult education by using electronic learning [11-14]. However, the focus should be on learning achievement and learner outcomes. Today's students should be prepared to be competent in the labour market after graduating from university when choosing an online program. It should be used for the benefits of both students and educational institutions where online programs are provided to society in open access.

\section{Acknowledgement}

This work was supported by Abai Kazakh National Pedagogical University, Kazakhstan / Ministry of Education and Science of the Republic of Kazakhstan and Yogyakarta State University, Indonesia.

Cite this article as: Kassymova, G.; Triyono, B.; Dossayeva, S.; Akhmetova, A. (2019), Cognitive competence and electronic learning. Materials of International Practical Internet Conference "Challenges of Science". ISBN 978-601-323-144-0. Issue II, 2019. Page 153-158. https://doi.org/10.31643/2019.030

\section{References}

[1] Saul Kassin. Psychology. Second edition. Printed in the United States of America. 1997. -P. 9-10

[2] Online Collins dictionary. 10.10. 2019. Retrieved from the webpage: https://www.collinsdictionary.com/dictionary/english/cognitive

[3] Online vocabulary dictionary. 10.10. 2019. Retrieved from the webpage: https://www.vocabulary.com/dictionary/cognitive

[4] Synonyms for the cognoscente. 10.10. 2019. Retrieved from the webpage: https://www.merriamwebster.com/dictionary/cognoscente\#h1

[5] Kassymova, G., Arpentieva, M., Kosherbayeva, A., Triyono, M., Sangilbayev, O., Kenzhaliyev, B. K. (2019). Science, education \& cognitive competence based on E-learning. The Bulletin. №1(377). -P. 269-278 https://doi.org/10.32014/2019.2518-1467.31 


\section{Materials of International Practical Internet Conference "Challenges of Science”}

[6] Ruben Iriondo Otero, W. (2012). Developing high-level cognitive skills in e-learning. Inter-Science Place, 1(20), $41-57$. https://doi.org/10.6020/1679-9844/2003

[7] Zoller, Uri and Pushkin, David. Matching higher-order cognitive skills promotion goals with problem-based laboratory practice in a freshman organic chemistry course. Chem. Educ. Res. Pract., 2007, №8(2), -P. 153-171

[8] Tim Kautz, James J. Heckman, Ron Diris, Bas ter Weel, Lex Borghans. Fostering and Measuring Skills: Improving Cognitive and Non-Cognitive Skills to Promote Lifetime Success. May 10, 2017.

https://www.oecd.org/education/ceri/Fostering-and-Measuring-Skills-Improving-Cognitive-and-Non-Cognitive-Skills-toPromote-Lifetime-Success.pdf

[9] Roberts, J. J., 2019, 'Online learning as a form of distance education: Linking formation learning in theology to the theories of distance education', HTS Teologiese Studies/Theological Studies 75(1), a5345. https://doi.org/10.4102/hts.v75i1.5345

[10] Online Education and Mega-Universities: Factors to Consider. By Melissa Venable, Ph.D., published on November 01, 2019. URL: https://www.bestcolleges.com/blog/online-education-and-mega-universities/

[11] Atayeva M., Putro, N. H. P. S., Kassymova G., Kosbay S. (2019) Impact of reading on students' writing ability. Materials of International Practical Internet Conference "Challenges of Science". ISBN 978-601-323-144-0. Issue II, 2019. Page 5-13. https://doi.org/10.31643/2019.001

[12] Kassymova, G. (2018). Competence and its implications. Challenges of Science. https://doi.org/10.31643/2018.063

[13] Atayeva, M., Ciptaningrum, D. S., Hidayah, R., Kassymova, G. K., Dossayeva, S. K. (2019). Cultivating junior high school students' critical thinking skills by using a short-video in english language classroom. The Bulletin, 5(381), 57-69. https://doi.org/10.32014/2019.2518-1467.124

[14] Gadirova T. R. (2019), Epigenetic mechanisms in cognitive development. Materials of International Practical Internet Conference "Challenges of Science". ISBN 978-601-323-144-0. Issue II, -P.: 48-54. https://doi.org/10.31643/2019.008 